\title{
First Report on Pea Seed-borne Mosaic Virus in Hungary
}

\author{
A. ALMÁSI, R. BOROS, K. SALÁNKI and B. BARNA* \\ Plant Protection Institute, Centre for Agricultural Research \\ P.O.B. 102, H-1525 Budapest, Hungary
}

(Received: 7 September 2020; accepted: 22 September 2020)

\begin{abstract}
One of the most important diseases of pea is caused by Pea seed-borne mosaic virus (PSbMV), which has a relatively wide host range. Since there are few varieties with resistance against the virus, and spraying insecticides is not very effective, the determination of the disease and the pathogen in the seeds is very important. Inoculum prepared from pea seeds showing typical virus symptoms caused very mild symptoms on Chenopodium amaranticolor and C. quinoa, but several chlorotic/necrotic lesions on bean (Phaseolus vulgaris) cv. Scarlet, and systemic symptoms with mosaic and curling of top leaves on bean cv. Maxidor. The detection of the virus was carried out by PCR using universal primers and virus sequence analysis. According to the phylogenetic analysis the PSbMV isolate identified in Hungary belongs to the pathotype P1 and associated with the cluster 2 isolates.
\end{abstract}

Keywords: Pea, bean, test plants, PCR, universal primer, virus sequence analysis.

PSbMV is a worldwide distributed, economically important seed-borne potyvirus, which infects pea and many other legume crops (Makkouk et al., 2012). In addition to infected pea seeds the virus is spread by aphid vectors in a non-persistent manner, but can infect also by mechanical inoculation (wind). Although PSbMV can cause significant yield and quality losses in pea, the effect on crop growth and yield is often missed as leaf symptoms are difficult to detect. Leaf symptoms include faint mottle and downward rolling and affected plants show mild stunting but the leaves sometimes remain completely asymptomatic. The discoloration and the reduced size of the seed are also characteristic features of PSbMV infection (Congdon et al., 2017).

The control of the disease raises some questions as well. Although there are efforts for breeding resistant genotypes worldwide, currently there are only few resistant varieties available (Van Leur et al., 2013a; Congdon et al. 2016). In addition, spraying insecticides is unlikely to be of real benefit because insecticides do not act fast enough to prevent the rapid spread of the virus by aphids. An important point in the control of disease is the use of healthy seed from virus-tested seed stock (Smýkal et al., 2010). Therefore a first step in the effective control of the disease is the determination of the disease and the pathogen in the seeds (Giakountis et al., 2015, Gheshlaghi et al., 2019; Van Leur et al., 2013b). 
In the Vegetable Research Institute, Kecskemét on pea breeding fields diseased plants were observed with symptoms suggesting PSbMV infection. In our study we have proved the infection of PSbMV, and to our best knowledge this is the first report on the identification of PSbMV in Hungary.

\section{Materials and Methods}

\section{Plant material, virus source and germination of seeds}

Visibly healthy and virus infected pea seeds (Pisum sativum, genotypes CS7, CS8 and AS8) were provided by Kinga Hütter (Vegetable Research Institute, Kecskemét) and were planted in pots and kept in greenhouse under normal conditions. In another experiment pea seeds were germinated in Petri dishes on wet filter paper at room temperature.

As test plants Chenopodium amaranticolor and C. quinoa, as well as different bean (Phaseolus vulgaris) varieties were inoculated.

For mechanical inoculations, $0.1 \mathrm{~g}$ of leaf material from virus-infected pea plants

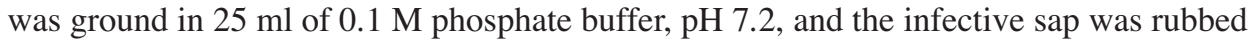
onto leaves without abrasive. The symptoms were evaluated successively.

\section{Detection of the virus with universal primers}

Total nucleic acid was extracted from $50 \mathrm{mg}$ fresh pea leaves with the method described by White and Kaper (1989). First strand cDNA was synthetized with RevertAid First Strand cDNA Synthesis Kit (ThermoScientific), with poly T2 reverse primer (5'-CGGGGATCCTCGAGAAGCTTTTTTTTTTTTTTTTT-3') and the PCR amplification of the $\mathrm{C}$ terminal region of the $\mathrm{NIb}$, the complete coat protein and the complete 3'UTR region was carried out with universal potyvirus forward primer poty7941 (5'-GGAATTCCCGCGGNAAYAAYAGYGGNCARC C-3') and poly T2 primers according to Salamon and Palkovics (2005). The PCR product was detected in 1.5\% agarose gel electrophoresis in standard manner. The PCR products about 1600 bp length were excised and purified with High Pure PCR Product Purification Kit (ROCHE) then cloned into pGEM $₫$-T Easy vector (Promega). The nucleotide sequences were determined (BIOMI) and deposited in the GeneBank.

\section{Virus sequence analysis}

The 1658 bp nucleotide sequence of the 5' terminal (Nter) 5' NIb-CP-UTR3' region of the Hungarian isolate was aligned with 12 other PSbMV sequences available from the GenBank (Table 1) using the ClustalW algorithm. Phylogenetic tree was composed by Maximum Likelihood method with 1000 bootstrap replicates using Tamura-Nei model (Tamura and Nei, 1993) in MEGA X (Kumar et al., 2018). 
Table 1

GenBank accession numbers of the PSbMV strains selected in this study for phylogenetic analysis

\begin{tabular}{llll}
\hline Strain & Origin & Pathotype & GenBank accession number \\
\hline Kreis Stormarn_18 & Germany & unknown & MN399737 \\
PSB194CZ & Czech Republic & P1 & MK116871 \\
US & USA & P1 & AF127768 \\
DPD1 & Denmark & P1 & D10930 \\
L1 & Denmark & P2 & AJ252242 \\
CAN (PV0316) & Canada & P1 & Z48508 \\
PK9 & Pakistan & P1 & AF127769 \\
NZ & New Zealand & P1 & D10453 \\
PSB178CZ & Czech Republic & P1 & EU293761 \\
GER & Germany & not published & Z48509 \\
PSB117CZ & Czech Republic & P1 & EU293758 \\
PSB58CZ & Czech Republic & P4 & EU293765 \\
\hline
\end{tabular}

\section{Results}

\section{Symptoms on seeds and plants}

The supposedly virus infected seeds showed necrotic rings and line patterns on the seed coat, malformation, splitting and reduced seed size (Fig. 1). The infected seeds germinated less percent than the healthy ones, and produced somewhat smaller seedlings compared to the healthy seedlings (data not provided). Otherwise no or very mild symptoms were detected on the virus infected plants.

\section{Symptoms on test plants}

On Chenopodium amaranticolor and C. quinoa plants chlorotic lesions developed, but just one or two lesions per leaf were observed. On Nicotiana tabacum L. cv Xanthi and on Nicotiana benthamiana plants symptoms were not detected even three weeks after the inoculation.

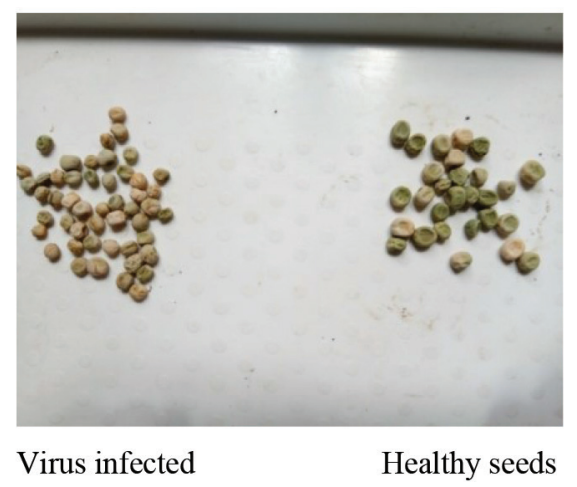

Fig. 1. Symptoms on virus infected pea seeds as compared to the control seeds 
However, on the leaves of bean cv. Scarlet large number of chlorotic/necrotic lesions developed (Fig. 2A.). On the other hand, on bean cv. Maxidor strong systemic symptoms with mosaic and curling of top leaves were detected (Fig. 2B).
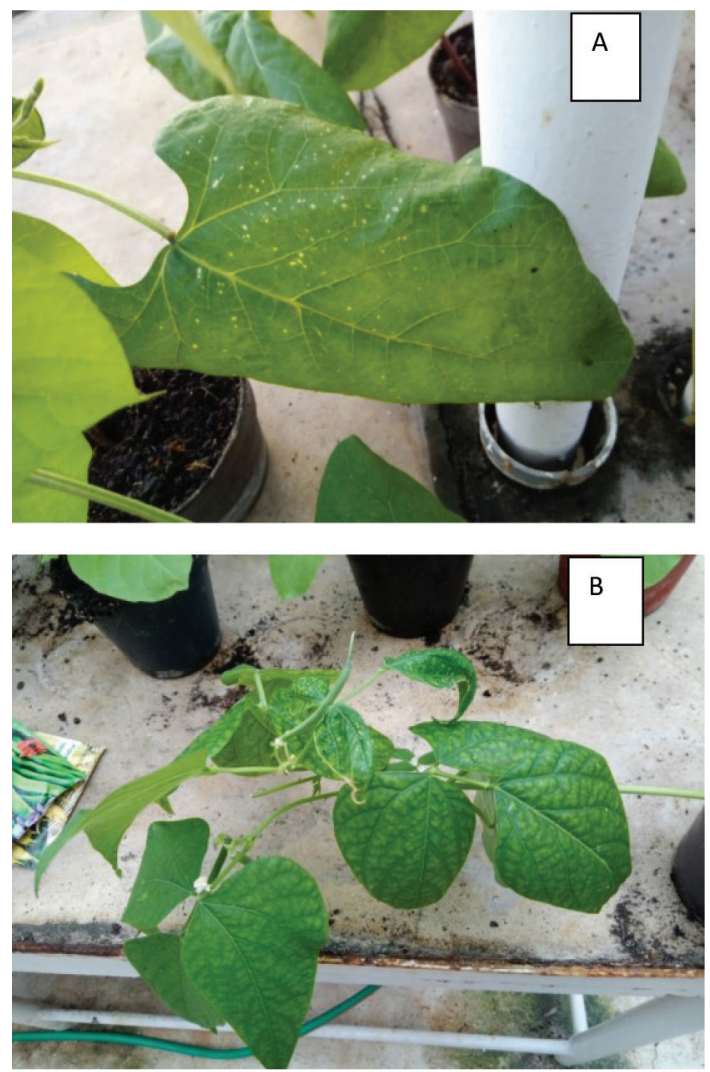

Fig 2. Virus symptoms on different bean cultivars (A):

chlorotic local lesions on leaves cv. Scarlet (B) systemic symptoms on cv. Maxidor

\section{Detection of the virus with universal primers and virus sequence analysis}

The 5' region of the NIb, the complete CP and the 3' UTR region of the analyzed isolate was amplified using RT-PCR. The amplification with universal primers described by Salamon and Palkovics (2005) was successful resulting an approximately $1700 \mathrm{nt}$ long fragment. The fragment was cloned and sequenced successfully. The identity of the cloned potyvirus was determined as PSbMV according to the BLAST algorithm in GenBank sequences (Table 1). The highest identity, 99. 22\% was detected with an unpublished PSbMV strain (MN399737) collected in Germany in 2018 proving the identification of PSbMV in Hungary. The determined nucleotide sequence of the Hungarian isolate was deposited in GenBank (Acc. No.: MT951241). 


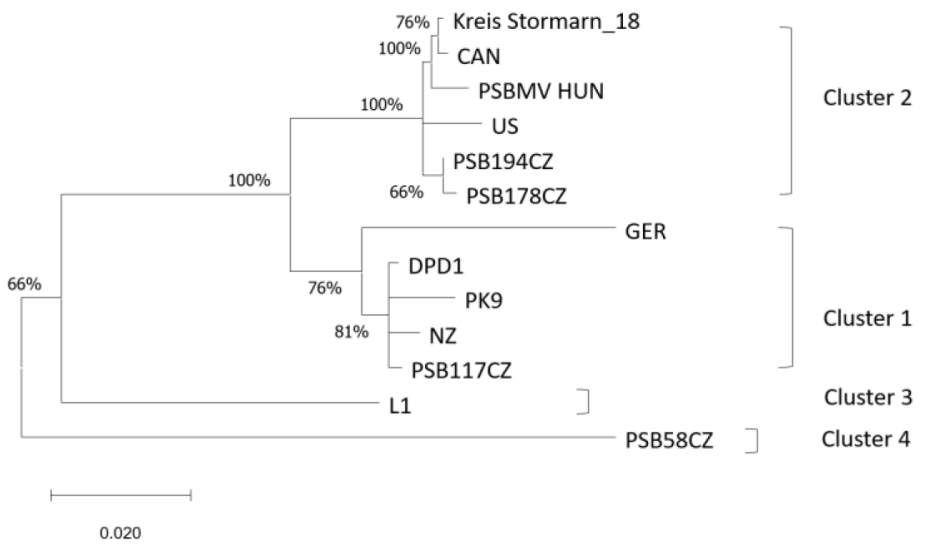

Fig.3. Phylogenetic tree based on the nucleotide sequences of the 5' terminal of the NIb-CP-UTR3' region. Maximum likelihood tree with 1000 bootstrap replicates was composed of PSbMV strains retrieved from GenBank and the newly isolated Hungarian strain (PBSMV HUN)

Phylogenetic analysis based on the nucleotide sequences of the $5^{\prime}$ terminal (Nter) encompass the 1100 bp 5' NIb-CP-UTR3' region was carried out (Fig. 3). This analysis involved the nucleotide sequences of pathotype 1 (P1) isolates including cluster 1 (PSB117CZ, NZ, DPD1, PK9) and cluster 2 (PSB178CZ, CAN, US), cluster 3 contains the pathotype 2 strain (L1) and cluster 4 involves pathotype 4 (PSB58CZ) isolates were also represented. According to the phylogenetic analysis the PSbMV isolate identified in Hungary belongs to the pathotype P1 and associated with the cluster 2 isolates. The origin of the isolates in this cluster is considerably diverse, originated from the USA, Canada and also from Europe namely from Czech Republic and Germany.

The isolates from Czech Republic show high diversity since they were located in three significantly distant cluster (1, 2 and 4) (Šafářová, et al., 2008) and even a recombinant isolate was detected (Navrátil and Šafářová, 2019). In this respect regarding the close geographical location further analysis of the PSbMV isolates in Hungary would be of primary interest especially in connection with resistance breeding (Wylie et al., 2011).

\section{Acknowledgment}

The financial support of the Hungarian Research, Development and Innovation Office (NKFIH K 124131) is gratefully acknowledged.

\section{Literature}

Congdon, B. S., Coutts, B. A., Renton, M., Banovic, M. and Jones, R. A. (2016): Pea seed-borne mosaic virus in field pea: widespread infection, genetic diversity and resistance gene effectiveness. Plant Dis. 100, 2475-2482.

Congdon, B. S., Coutts, B. A., Renton, M., van Leur. J. A. and Jones, R. A. (2017): Seed fractionation as a phytosanitary control measure for Pea seed-borne mosaic virus infection of field pea seed-stocks. Eur. J. Plant Pathol. 148, 733-737. 
Gheshlaghi, T. M., Shahraeen, N. and Rakhshandehroo, F. (2019): Serological and molecular characteristics of pea seed borne mosaic virus- PSbMV from lentil (Lens culinaris Medik L.) in Iran. Archives of Phytopathology and Plant Protection 52, 873-883.

Giakountis, A., Skoufa, A., Paplomatas, E. I., Tokatlidis, I. S. and Chatzivassiliou, E. K. (2015): Molecular characterization and phylogenetic analysis of a Greek lentil isolate of Pea seed-borne mosaic virus. Phytoparasitica. 43, 615-628.

Kumar, S., Stecher, G., Li, M., Knyaz, C. and Tamura K. (2018): MEGA X: Molecular Evolutionary Genetics Analysis across computing platforms. Molecular Biology and Evolution 35, 1547-1549.

Makkouk, K., Pappu, H. and Kumari, S. G. (2012): Virus diseases of peas, beans, and faba bean in the Mediterranean region. Adv. Virus Res. 84, 367-402.

Navrátil, M. and Šafářová, D. (2019): Naturally occurring recombinant isolate of pea seed-borne mosaic virus short communication. Plant Protection Science 55, 167-171.

Safárová, D., Navrátil, M., Petrusová, J., Pokorný, R. and Piáková, Z. (2008): Genetic and biological diversity of the Pea seed-borne mosaic virus isolates occurring in Czech Republic. Acta Virol. 52, 53-57.

Salamon, P. and Palkovics, L. (2005): Occurrence of Colombian datura virus in Brugmansia hybrids, Physalis peruviana L. and Solanum muricatum Ait. in Hungary. Acta Virologica 49, 117-122.

Smýkal, P., Šafářová, D., Navrátil, M. et al. (2010): Marker assisted pea breeding: eIF4E allele specific markers to pea seed-borne mosaic virus (PSbMV) resistance. Mol. Breeding 26, 425-438.

Tamura, K. and Nei, M. (1993): Estimation of the number of nucleotide substitutions in the control region of mitochondrial DNA in humans and chimpanzees. Molecular Biology and Evolution 10, 512-526.

Van Leur, J. A., Freeman, A. E., Aftab, M., Spackman, M., Redden, B. and Materne, M. (2013a): Identification of seed-borne Pea seed-borne mosaic virus in lentil (Lens culinaris) germplasm and strategies to avoid its introduction in commercial Australian lentil fields. Australasian Plant Dis Notes. 8, 75-77.

Van Leur, J. A., Kumari, S. G., Aftab, M., Leonforte, A. and Moore, S. (2013b): Virus resistance of Australian pea (Pisumsativum) varieties. New Zealand J. Crop and Horticultural Science, 41, 86-101.

White, J. L. and Kaper, J. M. (1989): A simple method for detection of viral satellite RNAs in small plant tissue samples. J. Virological Methods 23, 83-93. doi:10.1016/0166-0934(89)90122-5

Wylie, S. J., Coutts, B- A. and Jones, R. A. (2011): Genetic variability of the coat protein sequence of pea seedborne mosaic virus isolates and the current relationship between phylogenetic placement and resistance groups. Arch Virol. 156, 1287-1290.

Open Access statement. This is an open-access article distributed under the terms of the Creative Commons Attribution 4.0 International License (https://creativecommons.org/licenses/by/4.0/), which permits unrestricted use, distribution, and reproduction in any medium, provided the original author and source are credited, a link to the CC License is provided, and changes - if any - are indicated. (SID_1) 